\title{
Kropslige
perfektionerings- eksperter Om doping og andre
præstationsfremmende midler
i motions- og fitnessmiljøer
}

Af Inge Kryger Pedersen

Kroppe støder på granser ved byppig og intens fysisk traning. Ogsà selvom der indtages farmakologiske midler til at flytte på saidanne granser. Hvad der karakteriserer kropslige perfektioneringseksperter $i$ deves søgen efter bestemte prastationer og kroppe, bliver $i$ artiklen analyseret på baggrund af saivel kvalitative som kvantitative undersøgelser.

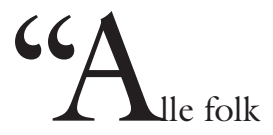

de går og drømmer om denne her pille, de kan spise, så de kan leve som svin og så stadigvæk være slanke som et sugerør. Og det er det her med at springe over, hvor gærdet er lavest. Det er nøjagtig det samme game, der giver sig udtryk $\mathrm{i}$ fitnessverdenen, når vi snakker anabolske steroider. Det er, at det går hurtigere, og det ved alle (...) Men de bieffekter, der kommer bagefter, dem har folk sgu ikke tænkt over, vel. Og mange gange så ender folk jo også med - fordi at konverteringen af de meget gode stoffer, den er rimelig høj til østrogen, og det vil sige, hvis de ikke tager produkter, der hæmmer østrogeneffekten, og det er der ikke nogen af dem, der kender noget til - så ender mange af dem jo med at blive småfede, når de er færdige med en kur, i stedet for at være muskuløse.”

Nybegyndere i en verden formet af kropslige erfaringer opnår ikke nødvendigvis den $\varnothing n s k e d e$ effekt. Det er ikke tilstrækkeligt at læse på internettet eller pilleglasset om 
muskelopbyggende hormoners dosis og virkning, hvis man vil være sikker på at fremstå med en muskeltrænet krop. Ovenstående er et citat af en dansk bodybuilder fra en interviewundersøgelse, som i denne artikel vil indgå i en analyse af, hvorledes steroidbrugere lever med og mod deres kroppe $i$ sindrige kombinationer af trænings-, kost og medicineringsregimer. Artiklen vil endvidere tage afsæt i spørgeskemaundersøgelser i danske motions- og fitnesscentre af anvendte midler og metoder til at forme kroppe og flytte grænser for præstationer.

\section{Materiale og MEtode}

Artiklen bygger på en spørgeskemaundersøgelse foretaget i 15 motions- og fitnesscentre udvalgt i forskellige områder af Danmark, samt på kvalitative interviews fra en igangværende undersøgelse i forskellige træningsmiljøer. Endvidere inddrages sociologisk og etnografisk litteratur om krop og fitnesskultur udover egne deltagerobservationer fra et halvt år $\mathrm{i}$ et amerikansk og tilsvarende i et dansk motions- og fitnesscenter.

Interviewmaterialet består af etnografiske, halvstrukturerede interviews med henholdsvis motions- og fitness- samt elitesportsudøvere. Fire interviews med styrketræningsudøvere, der har erfaringer med brug af anabole steroider, ${ }^{2}$ vil særligt blive anvendt til at belyse og perspektivere artiklens problemstillinger. Materialet skal ses på baggrund af en hermeneutisk-fænomenologisk bestræbelse. Hensigten har været at få interviewpersonerne til at beskrive centrale fænomener (træning; doping) så detaljeret som muligt ud fra fem spørgeguide-kategorier: Karriereforløb (trænings- og konkurrenceforløb), biografi (kendskab til og evt. erfaringer med doping- og andre præstationsfremmende midler), diskurs (italesættelse/tabuer omkring doping), kultur (viden/ sprog/praksis/normer/motiver/handel omkring farmakologiske midler), holdnin- ger (lov, regler, kontrol, information). Interviewene er transskriberet ordret med detaljer omkring pauser, følelsesmæssige udbrud m.v. og kodet og temaopdelt ved hjælp af computerprogrammet ATLAS/ti med kodeprocedurer fra 'grounded theory' (Strauss \& Corbin 1990).

Skønt anvendelse af etnografiske teknikker og principper fra et symbolsk interaktionistisk perspektiv (Spradley 1979, Strauss \& Corbin 1990) er der i det empiriske arbejde ikke set bort fra, at intervieweren skaber og indgår i interviewrummet ud fra en forforståelse og med en vis indflydelse. I erkendelse af dette samt også på baggrund af tilegnelsen af et forhåndskendskab til kulturen ved $\mathrm{i}$ alt et års deltagerobservation $\mathrm{i}$ to forskellige motions- og fitnesscentre og mangeårig sports- og dopingforskning kan interviewene betegnes som dybdegående interviews, foretaget med den hermeneutisk-fænomenologiske metodes bestræbelse på indlevelse. ${ }^{3}$

Endvidere vil den samfundsmæssige kontekst omkring brug af farmakologiske midler med henblik på at forme kroppe i styrketræningsmiljøer i højere grad blive inddraget, end det typisk ses i symbolsk interaktionistiske studier. Til gengxld vil artiklen afgrænse sig fra at behandle de sociale interaktioner, der udspiller sig i specifikke træningscentre, eller træningscentrenes selvpræsentation. Spørgsmålet om, hvilke sociale betingelser, der får sports-, idrætseller motionsudøvere til at anvende farmakologiske midler med henblik på at forbedre fysiske præstationer eller at forme kroppen på en bestemt måde, vil på en række områder blive indikeret; men artiklens diskussioner vil problematisere forklaringer af doping som udelukkende en effekt af social tvang. Samtidig tyder de kvantitative undersøgelser på, at der i spørgsmålet om doping er nogle sociale og kulturelle forhold, der så at sige går bagom ryggen på de involverede. Det galder eksempelvis den relative betydning af uddannelse, som er signifikant i motions- og fitnesscenterunder- 


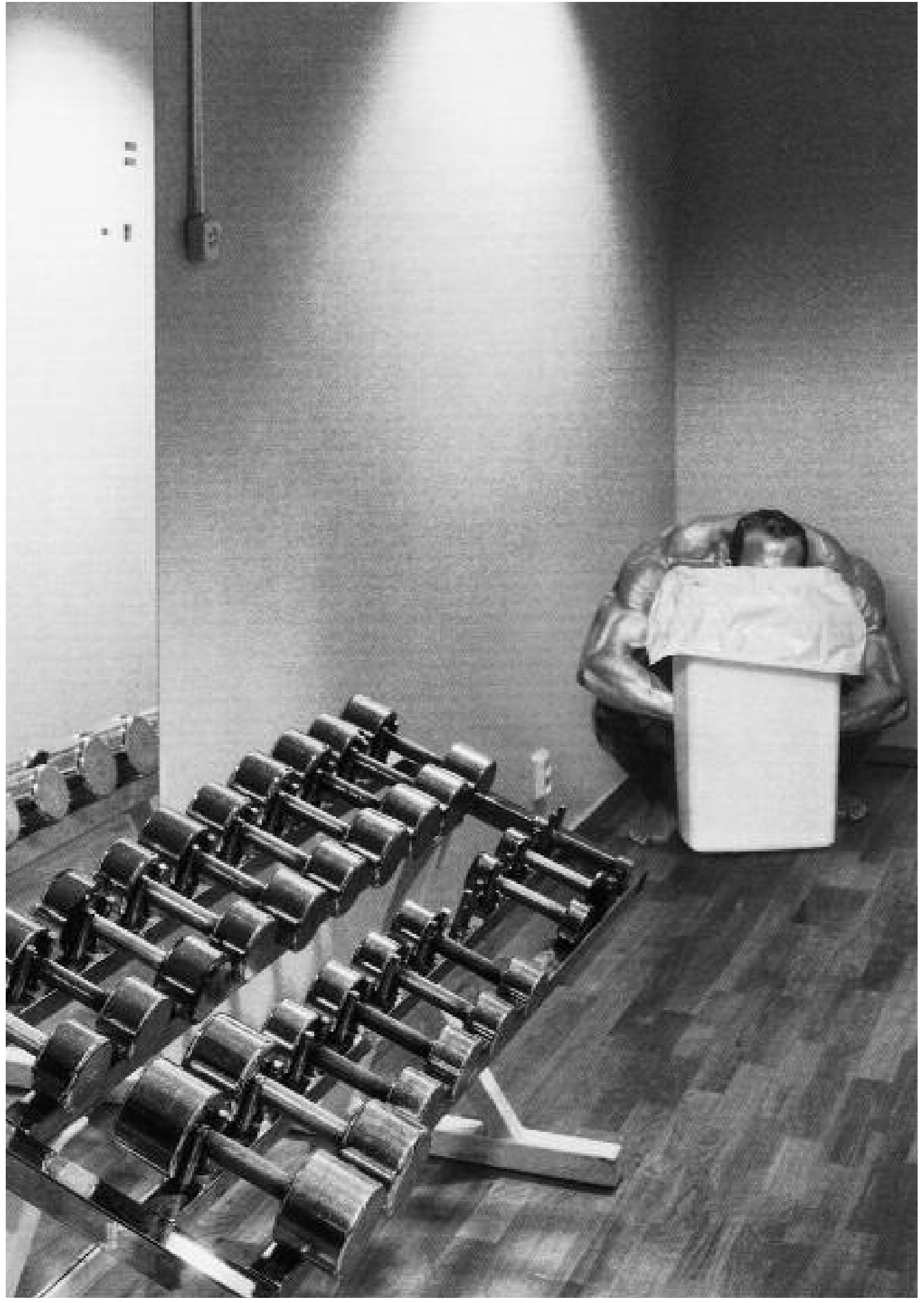


søgelsen, men ikke i undersøgelserne af doping i de øvrige idræts- og motionsmiljøer. Doping forklaret som et individuelt valg vil således også blive problematiseret. Med afsæt i det brede spektrum af undersøgelser og litteratur, der inddrages $i$ artiklens diskussioner, vil jeg argumentere for at betragte dopingfænomenet i fitnesskulturer i en dialektik mellem objektive, intersubjektive og subjektive facetter af det sociale træningsliv.

\section{UDBREDELSE AF DOPING}

Et stadigt stigende antal af et stikprøveudsnit af den danske befolkning har i Socialforskningsinstituttets (SFI's) jævnlige fritidsundersøgelser gennem de seneste fire tiår angivet, at de dyrker sport eller motion. Der er efterhånden sket en fuldstændig kønsudligning. Endvidere er der sket betydelige ændringer i aktivitetsmønstrene. En konkret anledning til med denne artikel netop at tage afsæe $\mathrm{i}$ fitnessinstitutionen er, at fysiske aktiviteter som aerobics, step, spinning, styrketræning boomer $\mathrm{i}$ disse år. Også i Danmark med en ellers stærk tradition for organiseret idrætsudøvelse i klubber og foreninger er der flere og flere, der træder deres aerobicssko og løfter deres vægte i motions- og fitnesscentre. 4

I SFI's seneste fritidsaktivitetsunders $\varnothing$ gelse fra slutningen af 1998 angiver $51 \%$ af et stikprøveudsnit af den voksne befolkning på 16 år og derover, at de "normalt dyrker sport eller motion", og 18 \% oplyser, at de går i motionscenter. Individuelle motionsaktiviteter har i løbet af de seneste tiår, ligesom i andre europæiske lande, overhalet flere af de gamle kerneaktiviteter, som i Danmark typisk har været fodbold og håndbold. Styrketræning er i 1998 tilsyneladende den fjerde største idrats- og motionsaktivitet (11 \% angiver at have dyrket styrketræning regelmæssigt det seneste år) og aerobics/workout den sjette største (7\% do.) (Fridberg 2000, 147).

Endvidere viser nye undersøgelser, at mange af kroppene ikke kun formes ved hjælp af fysisk træning og kostplaner, men også ved indtagelse af forskellige farmakologiske midler (Pedersen \& Benjaminsen 2002). Således svarer $4,7 \%$ af respondenterne $(\mathrm{N}=1036)$ fra en spørgeskemaundersøgelse i 15 danske motions- og fitnesscentre, at de har erfaring med illegale dopingmidler, hovedsageligt muskelopbyggende hormoner som anabole steroider. 5 14,1 \% af alle respondenterne svarer 'helt sikkert' eller 'muligvis' til, at de ville anvende dopingmidler, hvis de kunne opnå at få 'en flottere krop' (Benjaminsen \& Pedersen 2002a, 75).

Doping refererer i denne artikel til Den Internationale Olympiske Komités (IOC's) dopingdefinition 6 og omfatter de stoffer og metoder, som figurerede på IOC's dopingliste i foråret 1999 under udarbejdelsen af ovennævnte spørgeskemaundersøgelse. De mest kendte dopingmidler er forskellige former for anabole steroider samt væksthormoner og erythropoietin (EPO), der også alle er lovforbud imod at besidde, distribuere eller handle med i Danmark. Endvidere er stimulerende midler som efedrin og amfetamin kendte dopingmidler, og inden for idrættens verden var alle disse samt en række flere på undersøgelsestidspunktet, $i$ alt omkring 300 stoffer og mere end 15.000 typer af farmakologiske midler, også forbudte at have i kroppen.

På baggrund af en lang række undersøgelser kan det fastslås, at doping er et eksisterende potentiale i moderne industrisamfund: en lang række dopingmidler er tilgængelige, billige og med færre bivirkninger end tidligere, og de har nogle effekter, der stræbes efter i visse miljøer. Udover at pointere, at der naturligvis er en række kriminelle og helbredsmæssige aspekter på spil, skal jeg ikke her komme nærmere ind på mulige forklaringer på, at langt de fleste idræts- og motionsaktive ikke finder det aktuelt at dope sig.

At brug af dopingmidler dog ikke kun vedrører en eksklusiv skare, sandsynliggøres 
ved, at en nylig undersøgelse blandt 702 danske praktiserende læger viste, at $33 \%$ havde set patienter med bivirkningssymptomer fra især anabole steroider, $22 \%$ indenfor det seneste år (Dansk Sportsmedicin, 2002/4). Speciallæge i plastikkirurgi, Erik Løntoft, skønner endvidere, at mellem 50 og 100 danske mænd hvert år får fjernet bryster på grund af indtag af anabole steroider. Og læge i Anti Doping Danmark, Rasmus Damsgaard, bemærker, at tallet ville være højere, hvis et stort antal ikke tog medikamenter, der netop kan stoppe udviklingen af bryster. ${ }^{7}$

Doping og brug af andre prestationsfremmende midler forekommer altså ikke kun med henblik på at forbedre eliteudøveres sportslige præstationer. Det viser en række danske undersøgelser, vi foretog i forbindelse med udarbejdelsen af Kulturministeriets hvidbog om doping (Doping $i$ Danmark, 1999), og som ovenstående analyser bygger på. Doping finder også sted i miljøer, hvor det ikke nødvendigvis er præstationen, der er afgørende, men hvor målet måske snarere er en bestemt formning af kroppen, eksempelvis i styrketrænings- og bodybuildermiljøer. Spørgeskemaundersøgelserne indikerer imidlertid, at selvrapporterede erfaringer med og kendskab til dopingmidler ikke er tilfældigt spredt ud i hverken elitesport eller motions- og fitnessmiljøer. Der tegner sig ved nærmere analyse af svar fra 7.040 respondenter nogle mønstre i form af særlige former for doping og brug af andre præstationsfremmende midler i specifikke miljøer og grupper af respondenter (Pedersen \& Benjaminsen 2002).

Motions- og idrætsudøvernes køn og alder synes generelt at være blandt de faktorer, der har relativt størst betydning for, hvilke aktiviteter der foretrækkes (Larsen 2003, 23). Ligeledes er der signifikante køns- og aldersforskelle i den rapporterede erfaring med prestationsfremmende midler. Således viser undersøgelsen i de 15 motions- og fitnesscentre, at det især er yngre mænd, der er motiverede for at eksperimentere med de fleste af de prestationsfremmende midler, der er spurgt til. Men ikke alle. Andelen af kvinder, der rapporterede, at de brugte eller havde brugt slankemidler for at forbedre præstationen, var 16 $\% \bmod 8 \%$ af mændene (Doping $i$ Danmark 1999, 94). Ser vi på erfaringer med hovedsageligt muskelopbyggende hormoner, blev der svaret bekræftende fra 7,8 \% af de mandlige mod 1,4 \% af de kvindelige respondenter (Benjaminsen \& Pedersen 2002a, 14-15). I forlængelse heraf angav $62 \%$ af de mandlige respondenter det at gøre kroppen større som en væsentlig begrundelse for at træne, mod $12 \%$ af de kvindelige respondenter. Hvorimod $88 \%$ af de kvindelige respondenter angav det at få en mindre krop som en væsentlig begrundelse for at træne, mod $24 \%$ af de mandlige respondenter (Doping $i$ Danmark 1999, 87).

Med en kønsskillelinje baseret på, om respondenterne angiver at være 'kvinde' eller 'mand', tydeliggøres der altså en række generelle kønsforskelle i måderne at bruge og forme kroppen på i fitnessmiljøerne, omend den frivillige fysiske aktivitet efterhånden dyrkes af ligeså mange kvinder som mænd. Generelt anvender de kvindelige respondenter ikke de adspurgte midler $\mathrm{i}$ så stort et omfang, set i relation til mændene. Endvidere anvender de fleste kvinder tilsyneladende i høj grad andre midler end mændene, nemlig midler, der gør kroppen mindre.

\section{FORMNING AF KROPPE I FITNESSINSTITUTIONEN}

Der er visse lighedstræk mellem en række studier (Klein 1990, The Body Image Study 1992, Helling 1994, Barland 1997, Monaghan 2001) i form af sammenfaldende motiver blandt brugere af dopingmidler, i særdeleshed blandt mænd i forskellige bodybuildermiljøer. Først og fremmest drejer det sig om ønsket om at forbedre prestati- 


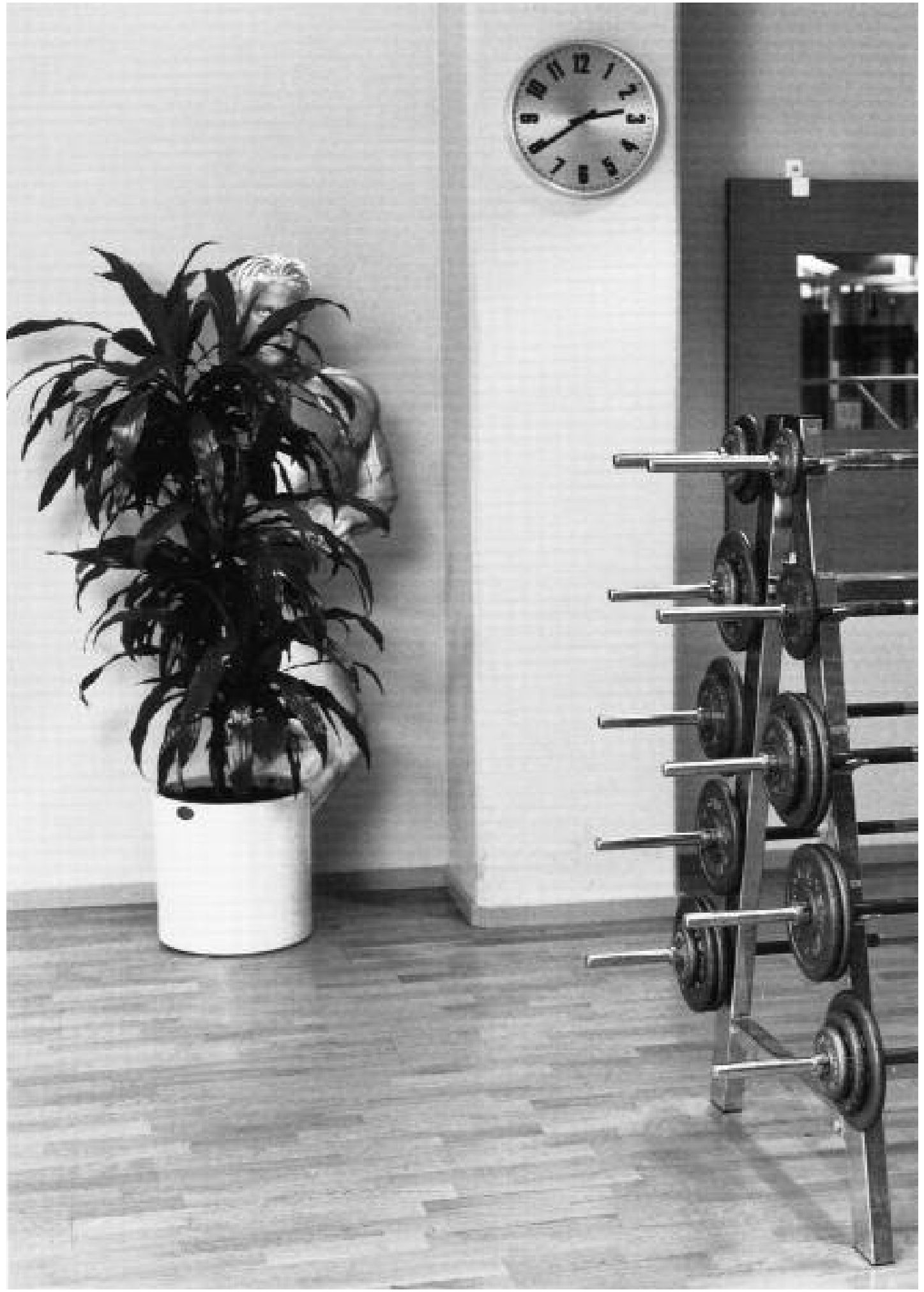


onen, at få øget muskelstyrke eller muskelvolumen. Der kan være stilstand i træningsfremgangen. Måske er tålmodigheden ikke stor nok til at træne ekstra. Og andre i træningsmiljøet fremviser muligvis en større fremgang og en større krop, eventuelt ved benyttelse af farmakologiske hjælpemidler. Herved bliver muligheden for brug af muskelopbyggende hormoner mere nærliggende. Motionscenteret bliver en form for hjem for de ihærdigt trænende, og sandsynligheden øges for, at man møder nogle med dopingerfaringer og adgang til forbudte midler.

Den norske idrætsforsker, Bjørn Barland, giver i Gymmet: en studie av trening, mat og dop (1997) et indlevende indblik i, hvorledes de lidt upræcise startmotiver for nybegyndere i styrketræningsmiljøer: "at have lyst til at træne" og "at komme i lidt bedre form" for nogle efterhånden kan udvikle sig til en form for besættelse: En livsstil omkring det projekt, det er at 'bygge' en bestemt kropsform og -størrelse. I nogle tilfælde anvendes farmakologiske midler som hjælpemiddel, i særdeleshed anabole steroider, i opbygningen af kroppen. Og i de danske undersøgelser er det en udbredt antagelse, at forbudte midler som muskelopbyggende hormoner relativt nemt kan anvises af nogle af de mænd, der træner med frie vægte og har nogle bestemte kropstegn.

I interviewene med danske elitesportsudøvere samt styrketrænende fra fitnessmiljøet træder to forskellige hovedforklaringer på brug af præstationsfremmende midler tydeligt frem. I sportens verden er forbedring af præstationen central i forskellige bud på motiver for doping (se også Pedersen 2002, 265-69), hvor det i motions- og fitnessmiljøerne i højere grad er bestemte kropsidealer. Men her inden for er der også forskelle, afhængigt af, om man er "Bulk" (voluminøs) eller "Cut" ('skåret'). Det canadiske The Body Image Study (1992) foretager denne distinktion i deres fokus på styrketrænendes brug af muskelopbyggende hormoner og henviser med "Bulk" til en praksis i tråd med længere traditioner og institutionaliseret viden blandt professionelle bodybuildere og med "Cut" til en praksis blandt oftest yngre, som ikke nødvendigvis er træningsentusiaster, men som gerne vil opnå (en genvej til) en mere muskuløs, men ikke voldsom voluminøs krop. Herudover er der en relativt lille andel kvinder, der benytter steroider. Udover kvindelige konkurrence bodybuildere er der en mindre andel, som ligesom "Cut"-brugere hurtigt vil opnå en mere muskuløs krop og tabe i (fedt)vægt.

Motions- og fitnessudøveres måder at forholde sig til træning og brug af præstationsfremmende midler på vil være omdrejningspunktet i det følgende, og mandlige udøveres subjektive erfaringsbeskrivelser omkring doping vil blive inddraget.

\section{VEJE TIL EN STØRRE KROP:}

\section{KALKULERET RISIKO}

Seks ud af de tyve interviewpersoner, jeg indtil nu har interviewet vedrørende mulige motiver til doping blandt henholdsvis elitesports- og motions- \& fitnessudøvere, har erfaringer med dopingmidler. Jeg vil her udelukkende referere til motions- og fitnessmiljøet og til fire af interviewpersonerne, som har følgende fællestræk: Alle fire har minimum to års erfaringer med anabole steroider og har startet deres styrketræning i almindelige motions- og fitnesscentre. Efter at have opnået en vis styrke fortsatte tre af dem i private centre med frie vægte og en høj andel af konkurrerende bodybuildere blandt de trænende.

På interviewtidspunktet var de fire dopingerfarne i alderen fra 27 til 46 år og havde forskellig uddannelsesmæssig baggrund, var enten under uddannelse eller i arbejde, fra ufaglært til akademisk arbejde. Alle påbegyndte brugen af steroider, da de var i 20'erne, og såvel køns-, alders- som uddannelsesspektrum stemmer overens med mønstret for dopingerfarne i den 
kvantitative undersøgelse. Det er endnu ikke lykkedes at inddrage kvinder med dopingerfaringer i interviewundersøgelsen, men et par af de mandlige interviewpersoner kender til enkelte kvinder, der bruger eller har brugt anabole steroider.

Tre af de fire har nylig erfaring, en af disse tager stadigvæk anabole steroider. Tre af dem har hovedsageligt holdt sig opdateret med viden om træning, kost og dopingmidler via internettet. Steroiderne har de erhvervet sig ved personlig kontakt til sælgere med relation til træningsmiljøet. De har dog også benyttet sig af sydeuropxiske apoteker, hvor steroider ikke er receptpligtige. Handel via postforsendelse har to af dem kun i mindre omfang benyttet sig af og har begge måttet betale bøder ved toldvæsenets afsløringer.

Der er både fællestræk og væsentlige forskelle i de motiver, de angiver for at have påbegyndt brugen af anabole steroider. Udseendet - det at få en større og mere muskuløs krop - er et gennemgående træk i begrundelserne for at styrketræne:

“Jeg var en lille lort på - hvad fa'n vejede jeg dengang? En 59-60 kilo, eller sådan noget i den stil. Og der har sikkert ligget nogle ting, rent psykologisk, at man godt ville være større. Og jeg har altid syntes, at en veltrænet krop var pæn, og det er selvfølgelig mange gange det, der har været med til at starte det. Det er, at det man har, det er man ikke tilfreds med. Det vil man gerne ændre på.”

To af interviewpersonerne deltog også i konkurrencer, den ene inden for bodybuilding, den anden inden for styrkekrævende idretsgrene. For disse to har præstationsaspektet ydermere spillet en rolle. En stilstand i træningsfremgangen efter nogle års ihærdig træning har imidlertid for alle fire aktualiseret overvejelserne omkring brug af muskelopbyggende hormoner.

“Man bliver jo 'sulten', man vil jo hele tiden mere og mere. Arnold Schwarzenegger sagde jo også: “Stay hungry!” Så man bliver aldrig tilfreds. Det er den evige jagt på kick'et, som aldrig ophører. (...) Men resultaterne stagnerer så. Lige pludselig så vokser du ikke mere, fordi du har nået dit fysiske maksimum (...) ... der er vel gået 1? år eller sådan noget, vil jeg tro, 2 år.

- Så mærkede du, at du var nået dit maksimum?

Ja, så skete der bare ikke mere, vel. Og så var det sådan, at jeg så tænkte: Nå, hvad kan man så gøre for at vokse noget mere? Og så .. jah ...”

Psykiske problemer fremhæves af to af dem som yderligere en anledning til at eksperimentere med en farmakologisk forstærket muskelopbygning. Den ene angiver forudgående "fest-, narkoforbrug eller -misbrug" som grunden til psykiske problemer forbundet med angst, hvor den anden nævner problemer med forældre og senere med kæreste. Muskelopbygningen synes at forstærke selvtilliden og have en positiv effekt på humøret, hvor pauserne imellem 'kurene' (typisk tages steroiderne 1-2 måneder ad gangen med minimum ligeså lange og op til dobbelt så lange pauser imellem) angiveligt har en negativ effekt. En af dem, der bevidst forberedte sig på problemet med fysisk og psykisk nedtur mellem kurene, siger om sine iagttagelser af de andre:

"Og det, jeg oplevede med mange af brugerne, det var også, at de blev fanget af det psykiske spil. Og fordi det, jeg også læste mig frem til, og som de også advarede imod, det er at sige, jamen, det, der sker, når man stopper en kur, det er jo, at en stor del af den styrkefremgang og den muskelmasse, man har opbygget, den taber man igen. Jeg plejer at sige, at hvis man er rigtig dygtig med sin trxning og sin ernæring, så kan man måske holde $50 \%$ af det, man har lagt på. Mange de taber hele pivtøjet igen. Og det er et problem rent psykologisk. Fordi hvis du har været vant til at kunne bænke 150 kilo, pludselig kan du kun bænke 100. Jamen, så har du et psykolo- 
gisk problem, fordi at du kunne engang noget andet. Du begynder at tabe dig igen, og for en bodybuilder, der har lagt mange kilo på og ser - altså hans målsætning det er, at vægtskalaen skal øges og så pludselig ser, den begynder at falde. Jamen, så har han ikke succes med sin træning, hvis man kan sige det på den måde. Og det game er der rigtig, rigtig mange, der er blevet fanget i. Altså fordi det, folk bliver afhængige af, det er jo ikke, at stoffet det er vanedannende eller på nogen måde. Det, de bliver fanget $i$, det er den psykiske vane $i$ at have træningsfremgang og $i$ at være stor og være stærk."

Selvom der med styrketræningen blandt de interviewede har været tale om yderst individuel træning, hvor de fremstår som deres egne eksperter i dosering af såvel træningsmængde, -intensitet som kost, kosttilskud og præstationsfremmende midler, relaterer de konstant deres udseende og træning til andre, der har befundet sig i samme træningsmiljø:

“... det [er] jo klart nok, at hvis der så er én i den gruppe, der pludselig finder ud af at sige: 'Jamen okay, det her har jeg ikke tålmodighed til - jeg begynder at bruge 'krudt' [steroider].' Så kan alle de andre jo godt se - bum, hvad fanden skete der dér, ik. Fordi de har jo gået og trænet sammen med ham, og nu vejer han lige pludselig 7-8 kilo mere end dem og er blevet meget stærkere og alt muligt andet, ik. Og det er jo som regel det, der giver denne her bieffekt af, at det virker som om, at det er et eller andet socialt. Jamen, det er det jo ikke. Det er jo fordi, de siger: 'Okay, hvis han kan, så kan jeg også.”

Tre ud af de fire har haft bivirkninger af brugen af anabole steroider. Den ene blev først gjort bekendt med betydelige bivirkninger, da han deltog i et lægevidenskabeligt forsøg. Via blodprøver blev han gjort opmærksom på alvorlige nyreproblemer som en følge af steroidbrug. At han netop ikke selv havde mærket til bivirkninger, ${ }^{12}$ har skræmt ham fra yderligere brug, hvorimod de øvrige interviewpersoner virker overbeviste om, at de selv kan/har kunnet styre alvorlige bivirkninger. To af dem er imidlertid blevet opereret for gynækomasti (udvikling af bryster). Hensynet til helbredet angives i de danske spørgeskemaundersøgelser at være den væsentligste begrundelse for ikke at bruge dopingmidler hos de respondenter, der ved en rakke svarmuligheder ellers angiver, at de kunne være potentielt interesserede. Således svarer generelt $10-15 \%$ i alle undersøgelserne, at det er af helbredsmæssige grunde, de ikke har brugt dopingmidler, hvor det er lavere andele, der angiver andre grunde, fx at det er ulovligt (Pedersen \& Benjaminsen 2002, 66-76).

To af interviewpersonerne kender til dopingerfarne med så alvorlige bivirkninger, at de er døde af det. De henfører dog disse til ekstreme brugere, der har eksperimenteret med overdrevne doseringer uden tilstrækkelige pauser og med indtagelse af flere forskellige midler på én gang.

"Mange af dem, jeg har hørt om, der har stillet træskoene, det er gået galt for, det har været dem, der har kørt på mere eller mindre nonstop. De har ikke holdt pause, de har ikke givet leveren tid til at blive renset og lige finde sig selv igen eller få kroppens hormonsystem til at falde i balance igen. Det har bare været ba-bu derudaf. Eller hvis de har holdt en pause, så har det været på to måneder, $\mathrm{i}$ løbet af et helt år.”

Efter de fire dopingerfarnes opfattelse synes fordelene ved brug dog at have opvejet bivirkningerne, omend alle er så opmærksomme på helbredsrisici, at de ikke vil anbefale andre at bruge anabole steroider. De retfærdiggør imidlertid deres egne dopingerfaringer overfor andre og sig selv på forskellig vis. Fx siger en af dem:

"Når folk kommer til mig og siger: 'Jamen, det må du ikke tage, det er så og så sundheds- 


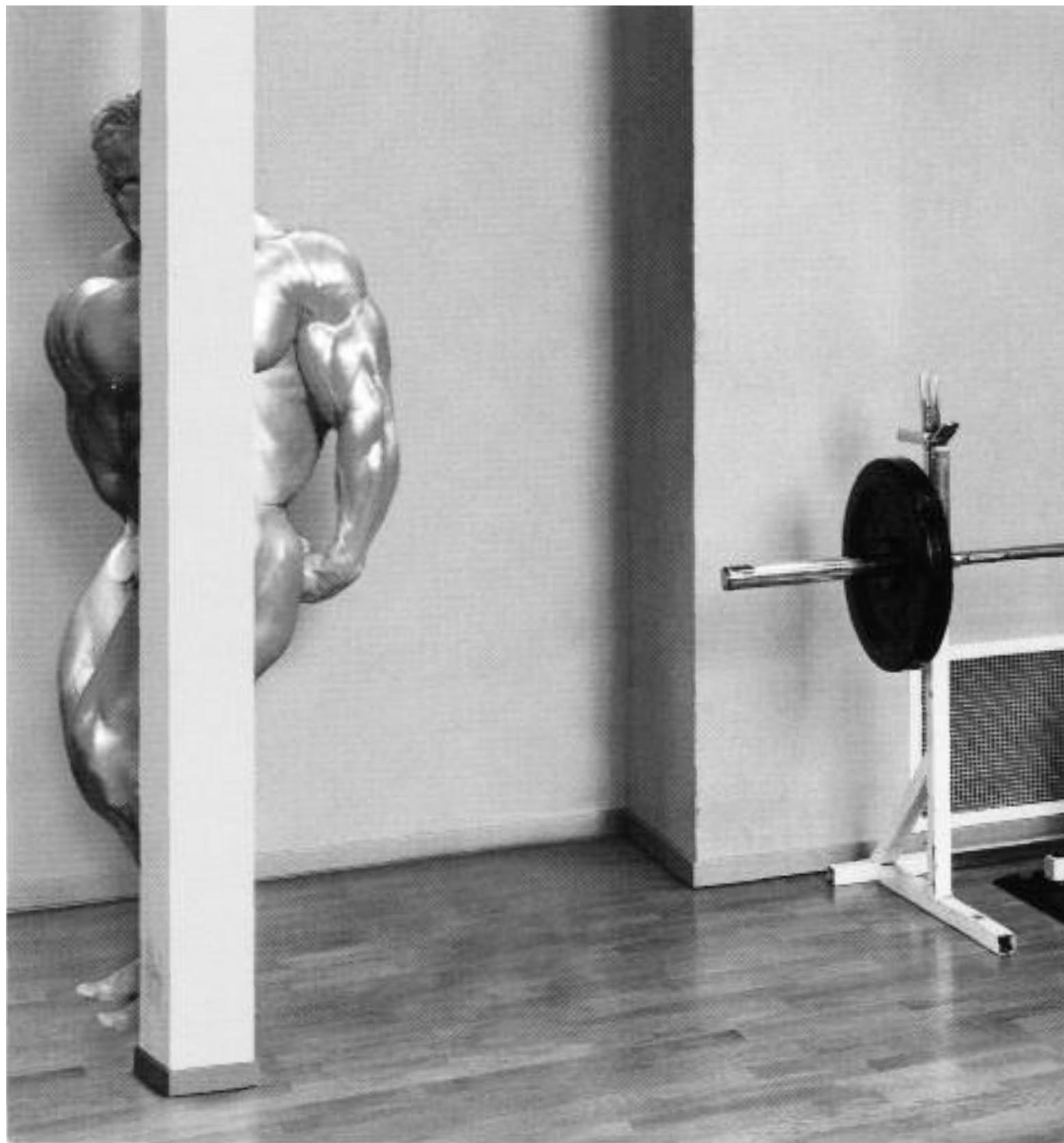

Anti Doping Danmark 


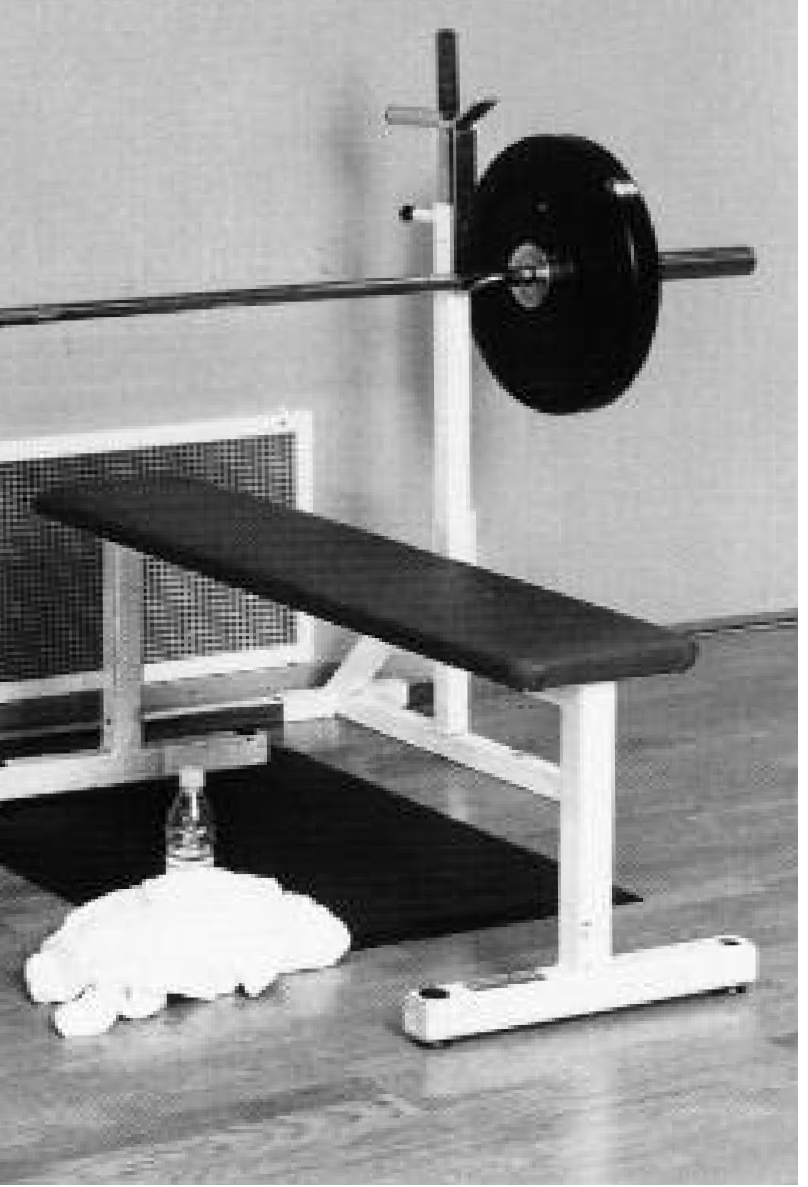

skadeligt.' Så siger jeg: 'Ja, det er nok muligt, men jeg mener med den viden, jeg har, da er det det, man kalder en kalkuleret risiko.' Jeg kan så vende den om og sige, jeg ryger ikke, jeg drikker ikke, jeg går ikke i byen hver weekend og sidder og er pilhamrende stiv. Jeg tager ikke alle mulige andre kemiske stoffer. Det er der så mange andre, der gør. Og så kan jeg så sige: 'Jamen $\mathrm{OK}$, hvem er så mest sund?’ Altså jeg har tit oplevet, at der sidder en eller anden halvfed gut på omkring de 40 og ryger cigaretter og drikker bajer og siger: 'Harh, harh, hormonvrag!' Så kan jeg vende det om og sige: 'Jamen hallo, hvem af os to, tror du, der dør først?’ Altså fordi for mig virker det helt omvendt, fordi jeg har højst sandsynligt en sundere livsstil og lever sandsynligvis også længere (...).”

Ovenstående citater giver et indblik i, hvorledes mandlige interviewpersoner med steroiderfaring håndterer trænings- og medicineringsregimer, når målet er at få en større og mere muskuløs krop. Hvor det måske for udenforstående kan forekomme ubegribeligt, at nogle, der går så meget op i træning og kost, vil udsætte sit helbred ved at indtage store doser af medicin med henblik på en bestemt formning af kroppen, illustrerer citaterne, hvorledes steroidbrugerne giver en sådan praksis mening ved at placere andres livsstil længere nede i et sundhedshierarki. I det sidste citat formuleres brugen af steroider som forbundet med en "kalkuleret risiko". Herved tilkendegiver interviewpersonen, at han lever med en risiko, men at den er velovervejet, og at hans $\varnothing$ vrige praksis opvejer de risici, andre udsætter sig selv for, endog i højere grad, ved ikke at træne samt ved at ryge og drikke.

\section{VEJE TIL EN MINDRE KROP: HELSEBRINGENDE MIDDEL}

Om der anvendes dopingmidler og andre farmakologiske midler eller ej, så viser spørgeskemaundersøgelsen i motions- og fitnesscentrene, som nævnt, at de fleste af de 
kvindelige respondenter træner for at blive mindre. Den nordirske feminist Moya Lloyd underbygger i sin diskursanalyse af aerobics en sådan tendens (Lloyd 1996). Hun gør opmærksom på, at aerobics, som slår igennem i slutningen af 1970'erne, med sin musik og danseagtige serier mest er knyttet til 'det feminine', hvor styrketræningen i motions- og fitnesscentrene appellerer til 'det maskuline'.

Aerobics fremstiller hun som et middel til at forme en tidsbestemt kvindekrop og ser dette, i aerobicsudøvernes selvforståelse, helsebringende middel som en konkret magtoperation, der ikke blot fremhæver idealer, men også skaber kroppe, som i andre sammenhænge ikke knytter an til helse, men til patologisk adfærd og henviser her til bulimi og anorexia nervosa. Lloyd finder aerobics overset i en række analyser af praksis knyttet til kvinders søgen efter slankhed, og hun tager analytisk udgangspunkt i, at aerobics deler en "kontinuitetsakse" med spiseforstyrrelser som bulimi og anorexi, men har sin egen specifikke form for fysisk fremtoning, som harmonerer med en nutidig, vestlig, feminin æstetik.

Lloyd underbygger, hvorledes aerobics i træningsprogrammer, fitnesscentre, magasiner etc. forbindes med sundhed, fitness og omsorg for selvet, hvor spiseforstyrrelser forbindes med noget patologisk eller abnormt. En sådan absolut skelnen problematiserer hun ved at pointere, at den antipati mod fedt, der synliggøres i spiseforstyrrelser, eksisterer tilsvarende i aerobics-kulturen. Forskellene er ifølge Lloyd udelukkende at finde i magtoperationerne, afhængigt af om det er en sultet, asketisk krop eller en muskeltonet, aerobisk konditioneret krop, som bliver produceret.

Ved tekstanalyse (af videoer, magasiner, træningsmanualer etc.) forsøger Lloyd at demonstrere, at aerobics er indskrevet i en normaliserende struktur, som forsager fedt. Kvinder får via medier leveret en idealiseret version af kvindekroppen; men med aerobics får de også leveret et stykke "værktøj” (tool-kit) til at opnå disse idealer. Med den franske idéhistoriker Michel Foucaults begreber er der tale om et såkaldt "technicopolitical register of power": et sæt teknikker, reguleringer og metoder til at kontrollere eller korrigere kroppens operationer med.

Skulle man følge de paralleller, Lloyd anfører mellem aerobics og styrketræning, blot fordelt med forskellige værdier på henholdsvis feminine og maskuline udtryk, kunne styrketræning så ligge på en kontinuitetsakse med doping? Omend motiverne for såvel at påbegynde styrketræning som at anvende anabole steroider kan være forskellige fra person til person, synes en vis kropsfiksering at være en fællesnævner. Gennemgående i de tidligere nævnte undersø-gelser i bodybuildermiljøer påpeges manglende selvfølelse og en forvrænget kropsopfattelse at være knyttet til de første erfaringer med muskelopbyggende hormoner. De samme karakteristika knyttes i andre studier også til anorektisk adfærd. ${ }^{9}$

Den perfekte krop - stor eller lille - kan være et tegn til omverdenen på, at man har styr på sig selv. En voluminøs krop bliver et tegn på en livsstil, der hænger nøje sammen med doping, træning og en bestemt kost. Om den enkelte er et fuldgyldigt 'medlem' af en sådan kultur, hænger sammen med kroppens udseende. En vellykket kropsfremtoning signalerer selvkontrol og styrke. I nogle bodybuildermiljøer kan det give ekstreme udslag i form af kroppe, som ikke kan blive store nok. I denne sammenhæng er begrebet megareksi lanceret som en kontrast til anoreksi; men ligesom anoreksi, hvor kroppen ikke kan blive slank nok, kan det ses som et udtryk for et forstyrret kropsideal (Pope et al. 1993, Pedersen 1999).

\section{KROPSLIGE}

\section{PERFEKTIONERINGSEKSPERTER}

Såvel i sport som i fitness optræder hyppigt trænende som deres egne eksperter, der 
søger passende midler i perfektioneringen. Midlerne omfatter ikke altid udelukkende fysisk træning, fornuftige kostplaner, hvile samt samvær med kammerater og konkurrenter, men kan tilsyneladende spænde fra at lade være med at spise til indtagelse af diverse farmakologiske midler for at blive større.

Lloyds analyser af aerobics ud fra fokus på kontrol, disciplin og normativ tvang $\mathrm{i}$ formningen af kroppe er i stand til at belyse en fitnesskultur ud fra tvangsmæssige handlingsperspektiver med paralleller til spiseforstyrrelser og doping i søgningen af specifikke formninger af den feminine og den maskuline krop. ${ }^{10}$ Ligeledes har de fleste sociologiske perspektiver på dopingfænomenet, fx professionaliserings-, kommercialiserings- og medikaliseringstendenser (se også Pedersen 2003), fokus på, hvorledes kulturer kommer kropsligt til udtryk (embodiment). Perspektiverne forudsætter socialiserede og disciplinerede individer, som er i stand til at internalisere ydre kontrol eller at modificere de normer, som samfundsudviklingen eller forskellige institutioner pålægger dem.

Ved at illustrere styrketrænende udøveres måder at forholde sig til trænings- og medicineringsregimet på med deres egne stemmer er selvkontrollerede udøvere i fitnessinstitutionen ikke kun blevet fremstillet ved afmagtsmetaforer, som karakteriserer Lloyds analyse af aerobics-diskurserne. Således behandler denne artikels interviewundersøgelse af udøvernes motiver for træning samt indtagelse af anabole steroider en mere overset del af kropskulturforskningen, der til forskel fra spørgsmålet om embodiment omhandler individuelle projekter med at 'bygge' en krop op. Dopingmidlerne indgår i et medicinsk regime, som parallelt med træningsregimet indgår i et nærmest eksistentielt projekt i form af det at 'bygge' sin krop. Dertil kommer for det andet søgningen af 'effekter'. Gennem sociale kontakter og formidlet viden i miljøet, men i særdeleshed også gennem egne afprøvnin- ger nås frem til den rette individuelle 'kur' for såvel træning som indtagelse af stoffer (se også Helling 1984). For det tredje er viden om dopingmidler og deres effekter (endnu) ikke en institutionaliseret viden, og steroidbrugerne er placeret i en række mere eller mindre selvvalgte risici.

Med sidstnævnte perspektiv alene er der umiddelbart ingen ydre tvang. Den enkelte udøver konstruerer sin egen erfaring og viden, uafhængigt af samfundsmæssige institutioner, og formningen af kroppen vil inden for et sådant perspektiv være betinget af en høj grad af selvkontrol. En selvkontrol, som i foucaultsk forstand kunne betragtes som en askese, hvor det moralske subjekt former sit liv som et personligt kunstværk (Foucault 1988(1984)).

Der tegner sig med artiklens analyser således tre perspektiver på det fænomen, der passende kunne kaldes for kropslige perfektioneringseksperter, som:

1. konstruerer egen erfaring og viden, uafhængigt af institutioner (autonomt individ) 2. er i stand til at internalisere ydre kontrol (disciplineret, socialiseret individ)

3. modificerer og omprioriterer de normer, som institutioner pålægger (forhandlingsindivid)

Med det første perspektiv på kropslige perfektioneringseksperter er det muligt at bidrage til en forståelse af, hvorledes folks erfaringer og reaktioner på sociale strukturer formes af sansbare, kropsliggjorte selver. Ligeledes kan mere kødelige og sensuelle dimensioner af tætte, personlige relationer fremmes med den relevans for øje, at kroppen også lever et liv udenfor rationelle beslutninger og på trods af 'bærerens' tilegnelse af alskens viden. Hvis sådanne dimensioner overses, marginaliserer man en forståelse af, hvorfor nogle kroppe er ufleksible, også ligegyldigt hvor velreflekteret 'bæreren' er, eller hvor effektive de omgivende 'systemer' er. Her tænkes for eksempel på de tilfælde, hvor formningen af krop- 
pen søges styret ved at træne og følge en kostplan, men hvor kroppen ikke makker ret. Hvor en oprindelig intention om at tabe sig kan udvikle sig til en ufrivillig spiseforstyrrelse. Eller hvor formålet med indtagelse af steroider er at fremme udviklingen af muskler og et maskulint udseende, men hvor en af effekterne er udviklingen af bryster. Biologiske processer indgår således også i dette perspektiv på kropslige perfektioneringseksperters møjsommelige arbejde.

I en fortolkning af doping og kropsformning er det andet perspektiv, som er blevet udtrykt ved Lloyds analyser, væsentligt til at belyse, hvorledes kulturer manifesterer sig kropsligt. Sammen med det tredje perspektiv bidrager det til historiske og sociologiske forklaringer på forandringer af kropsidealer og -praksis, herunder doping. Men analyser af dopingerfaringer $i$ fitnesskulturen tyder på, at en teori om doping med udelukkende et tvangsmæssigt handlingsperspektiv næppe vil være i kontakt med sin genstand. ${ }^{11}$

\section{KONKLUSION}

Med afsæt i empiriske undersøgelser af træning i motions- og fitnesscentre har intentionen med artiklen været at undersøge, hvordan udøvere forholder sig til træningsog medicineringsregimer i de historiske og sociale betingelser, der nu er for kropslige praktikker i fitnessinstitutionen. Generelt formes kroppe forskelligt af mænd og kvinder, og nogle farmakologiske midler appellerer i højere grad til et dominerende mandeideal i dag: Han er for lille (viagra, væksthormoner) og for lidt aggressiv (steroider, amfetamin) og for pivet (smertestillende); andre appellerer til et generaliseret kvindeideal: Hun er for stor (vanddrivende midler, slankemidler) og hysterisk (anti-depressiva og midler mod PMS (premenstrual syndrome)). I denne formning har vi set, at kroppe kan yde modstand, og de synes ikke blot at være genstand for enten biologiske eller sociale tvangsprocesser.

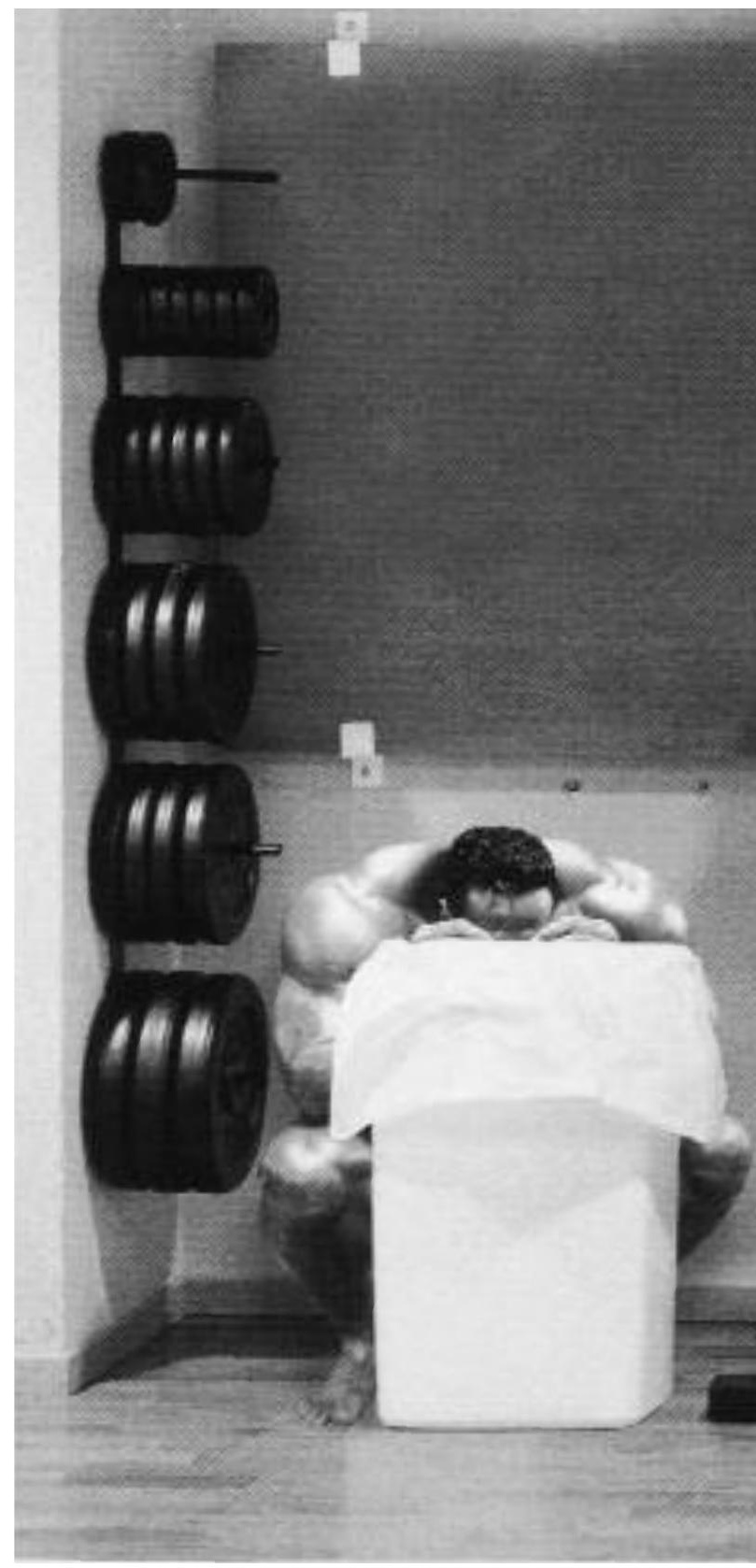


Kvinder kan i bestræbelsen på at fjerne fedt ved hjælp af steroider udvikle skæg, og mænd kan udvikle bryster. Men hvor opfattelsen af 'forkert' krop i slutningen af det 19. Århundrede var af teoretisk betydning ved at være knyttet til udviklingen af biologiske årsagsforklaringer, så har opfattelsen af 'forkerthed' i det 20. Århundrede derimod haft en mere pragmatisk betydning i takt med udviklingen af kosmetisk kirurgi m.v., idet 'forkertheden' efterhånden har kunnet korrigeres (Hirschauer 1998, 14). Således kan kroppe i fitnessinstitutionen også formes ved brug af præstationsfremmende, farmakologiske midler. Analysen af, hvorledes dette kan finde sted, er i artiklen ikke blevet skarpt opdelt i henholdsvis en objektiv social-kulturel side og en subjektiv inderlighedsside. Ved analyser af ekstreme cases som bodybuilderkulturer samt steroidbrugeres udsagn om kropslige erfaringer er det problematiseret, at doping udelukkende forklares som en effekt af social tvang. Samtidig har de kvantitative undersøgelser indikeret, at der i spørgsmålet om doping tilsyneladende er nogle sociale og kulturelle forhold, der så at sige går bagom ryggen på de involverede. Doping forklaret som et individuelt og rationelt valg er således også blevet problematiseret.

Når formålet var at nærme sig 'situationens rum' for bodybuildede kroppe i fitnessinstitutionen på fænomenologisk vis, hvor kroppen aldrig blot er et objekt i verden, kan det umiddelbart synes paradoksalt at fremvise, hvorledes kroppe af udøvere bliver omtalt og behandlet som 'maskiner', betragtet som 'ting' udenfor bevidstheden. Ikke desto mindre hviler denne fremstilling på 'levede erfaringer' (og ikke nødvendigvis på en kroppens ontologi), og den cartesianske dualisme understøttes erfaringsmæssigt (og ikke nødvendigvis begrebsmæssigt). Det gør den imidlertid netop i situationer, hvor intentioner og mål med træningen ikke kan opfyldes: når kroppen siger stop, og kropsformningen støder på grænser.

Disse fund kunne elaboreres videre $\mathrm{i}$ an- dre undersøgelser af kroppens grænser, fx også ved en række sygdomme. Er den gamle cartesianske opdeling i krop og sjæl netop så levedygtig i kraft af, at kroppen i en række problematiske eller reflekterede situationer opleves som en 'ting'?

Den kropslige perfektioneringsekspert, som er kommet til syne i artiklens analyser, står således ikke alene, men indgår i et dialektisk samspil med historiske og samfundsmæssige forandringer $i$ en fortolkning af kroppen og anvendelsen af midler til at forme den.

\section{NoTer}

1. Med titlen "Kvinder får skæg, og mænd får bryster" påpeger en artikel på Anti Doping Danmarks hjemmeside, at muskelopbyggende hormoner som anabole (androgene) steroider kan få kvinder til at ligne mænd. Det forekommer indlysende for mange, eftersom sådanne steroider dækker over det mandlige kønshormon, testosteron og testosteronlignende stoffer, der fremmer maskuline træk som dybe stemmer og skægvækst. Til gengæld er det ukendt for mange, at selvsamme stoffer har østrogendannende effekt og således kan fremme en udvikling af feminine træk hos mænd som eksempelvis udvikling af 'tævepatter' eller 'bitch tits' (http://undervisning.doping.dk/visArtikel.asp?artikellID=93).

2. For en etnofarmakologisk taxonomi over, hvad termen 'steroider' omfatter, se Monaghan 2001, 98.

3. En indlevelsesbestræbelse, som søges at lede til 'Verstehen', se også Abel 1964 samt Barbosa da Silva 1996, 188 ff. Iøvrigt ligger artiklens hermeneutisk-fænomenologiske bestræbelse - udover inspirationen fra Merleau-Pontys kropsfænomenologi - i kølvandet på Peter Berger \& Thomas Luckmanns fænomenologi om den sociale virkelighed (1979). Det er også i lyset af Berger \& Luckmanns tilgang, at artiklens inspiration fra den symbolske interaktionisme skal ses. Endvidere trækker Berger \& Luckmann fra en heideggersk snarere end fra en husserlsk fænomenologi en linie, der harmonerer med denne artikels ambition om at lade en historisk og sproglig forståelseshorisont indgå i en socialontologi snarere end 'intentionalitet' i essentialistisk forstand. Endelig fremhæver de en mulig sammenhæng mellem livsverdenen og menneskets 
biologisk-materielle 'natur' $(1979,211)$, hvis relevans trænger sig på, når interviewmaterialet tyder på, at fx effekten af anabole steroider udmønter sig på forskellig vis fra bruger til bruger.

4. For at illustrere de aktuelle ændringer af motionsaktivitetsmønstrene kan det nævnes, at blot i Københavnsområdet er det planen at åbne 20 nye motions- og fitnesscentre i 2004, heraf tre kæmpecentre: Equinox åbner i begyndelsen af året i Valby et center på 6.800 kvadratmeter og bliver herved Skandinaviens største. I løbet af foråret slår fitnesskæden, Hard Work Studio, rekorden med et 7.000 kvadratmeter stort fitnesscenter på Amager og slår sin egen rekord senere på året med et endnu større i Valby (Berlingske Tidende, 15. januar 2004).

5. Et $5 \%$-konfidensinterval om denne andel er $[3,4 \% ; 6,0 \%]$. Se evt. Pedersen \& Benjaminsen 2002 for udbredelse i andre idrætsmiljøer samt øvrige undersøgelsesspørgsmål, svarprocenter, overvejelser omkring underraportering m.v.

6. "Ved doping forstås tilstedeværelsen i den menneskelige organisme af stoffer, der er forbudt i henhold til den Internationale Olympiske Komités liste over forbudte stoffer. Brug af sådanne stoffer, tilstedeværelsen af sådanne stoffer i urin- eller blodprøve, samt anvendelse af metoder til at ændre analyseresultatet af en urinprøve eller blodprøve er forbudt." (Oversat fra International Olympic Committee Medical Code, 1995)

7. Se artikel på Anti Doping Danmarks hjemmeside:

http://undervisning.doping.dk/visArtikel.asp?artikellID=93, hvori det iøvrigt fremgår, at fjernelse af bryster hos mænd er den femte hyppigste operation på plastikkirurgiske klinikker i Californien.

8. Denne oplevelse af en relation mellem kroppen og selvet, der her via fysiologiske undersøgelser rækker hinsides erfaringen, kan parallelliseres til mulige oplevelser omkring det molekylære blik, genteknologien i langt mere vidtrækkende grad vil kunne bidrage til. En optik, der aktualiserer begrebet om 'somatisk individualitet', jf. Rose \& Novas 2002 .

9. Jfr. bl.a. Blouien et al. 1995 samt Schwerin \& Corcoran 1996. Det tidligere omtalte canadiske studie refererer ligeledes til tæet relaterede motiver mellem "Cut"-steroidbrugere og unge kvinder med spiseforstyrrelser (The Body Image Study 1992, 8).

10. For en parallel i bodybuildingstudier til Lloyds perspektiv, se fx Klein 1993. Som et supplement eller alternativ til et sådant perspektiv, se Monaghan 2001, som netop formår at vise mangfoldigheden i bodybuilderkulturen.

11. Disse tre perspektiver som en analytisk ramme til at karakterisere kropslige perfektioneringseksperter læner sig opad Berger \& Luckmanns (1979) dialektiske og sociologiske tilgang til en fænomenologisk belysning af den sociale verden.

12. Se Leder 1990 for en fænomenologisk udfoldelse af en sådan diskussion.

\section{LITTERATUR}

- Abel, T. (1964): "The Operation Called Verstehen", in H. Albert (ed): Theorie und Realität.

J.C.B. Mohr, Tübingen:

- Barbosa da Silva, António (1996): "Analys av texter", in P.-G. Svensson \& B. Starrin (red): Kvalitativa studier $i$ teori och praktik. Studentlitteratur, Lund.

- Barland, Bjørn (1997): Gymmet: en studie av trening, mat og dop. Oslo: Dr.Scient avhandling, NIH (Norges Idrettshøgskole).

- Benjaminsen, Lars \& Pedersen, Inge K. (2002) Doping og anvendelse af andre prestationsfremmende midler blandt brugere af danske motions- og fitnesscentre - en statistisk analyse. Sociologisk Rapportserie nr. 9. Sociologisk Institut, Københavns Universitet, København.

- Berger, Peter L. \& Luckmann, Thomas (1979[1966]): Den samfundsskabte virkelighed. Lindhardt og Ringhof, København.

- Blouien, Arthur G. et al. (1995): "Body image and steroid use in male bodybuilders", in International Journal of Eating Disorders, 2/18.

- Doping i Danmark. En hvidbog (1999): København: Kulturministeriet.

- Foucault, Michel (1988([1984]): The Use of Pleasure. The History of Sexuality, 2. Penguin Books, London.

· Helling, Stig (1994): Steroider och starka män. En djupintervjuundersökning. Centralförbundet för alkohol- och narkotikaupplysning, CAN-Rapport-serie nr. 38, Stockholm

- Hirschauer, Stefan (1998): "Performing Sexes and Genders in Medical Practices", in M. Berg \& A. Mol (eds): Differences in Medicine. Unraveling Practices, Techniques, and Bodies. Duke University Press, London.

- Klein, Alan M. (1993): Little Big Men. Bodybuilding Subculture and Gender Construction. State University of New York Press, N.Y. 1990: "Little Big Man: Hustling, Gender Narcissism, and Bodybuilding Culture", in M. A. Messner \& D. F. Sabo (eds): Sport, Men, and the Gender Order. Human Kinetics Books, Champaign. - Larsen, Knud (2003): Idratsdeltagelse og idratsforbrug i Danmark. Klim, Århus. 
- Leder, Drew (1990): The Absent Body. The University of Chicago Press, Chicago.

- Lloyd, Moya (1996): "Feminism, Aerobics and the Politics of the Body", in Body \& Society 2(2).

- Monaghan, Lee F. (2001): Bodybuilding, Drugs and Risk. Routledge, London.

· Pedersen, Inge Kryger (2003): "Lægemidlers indtog i sport og motion", in Social Kritik, 2003, nr. 90. (2002): "Eliten er mangfoldig - om doping i dansk eliteidræe", in H. Eichberg \& B. V. Madsen (Red.): Idrettens enhed eller mangfoldighed. Klim, Århus. (1999): "Han er for lille, og hun er for stor. Om doping og spiseforstyrrelser", in Sport \& Psyke 21-22. \& Benjaminsen, Lars (2002): Doping $i$ den danske befolkning og $i$ danske idrets- og motionsmiljøer. Sociologisk Rapportserie, 5. Sociologisk Institut, Københavns Universitet, København.

. Pope, Harrison G., Katz, David L. \& Hudson, James I. (1993): "Anorexia nervosa and "reverse anorexia" among 108 male bodybuilders", in Comprehensive Psychiatry, 6/34.

· Rose, Nikolas \& Novas, Carlos (2002): "Genetisk risiko og fødslen af det somatiske individ", in Slagmark-Tidsskrift for Idéhistorie, nr. 35.

- Schwerin, Michael J. \& Corcoran, Kevin J. (1996): "Beliefs about steroids: user vs. non-user comparisons", in Drug and Alcohol Dependence, nr. 40.

- Spradley, James. P. (1979): The Ethnographic Interview. Harcourt Brace Jovanovich College Publishers, New York.

- Strauss, Anselm \& Corbin, Juliet (1990): Basics of Qualitative Research. Grounded Theory Procedures and Techniques. Sage Publications, London.

- The Body Image Study. A Qualitative Study of the Use of Performance-Enhancing Drugs by Non-Athletes (1992), Canadian Centre for Drug-Free Sport

\section{SUMMARY}

Using data obtained from interviews, participant observation and questionnaires, this article explores what initiates and legitimates potentially dangerous taking of steroids to become bigger or diet products to become slimmer within fitness culture. As a bodily expert exercising self-supervision, but unintelligible within the perspective of the self as such, the user of performance-enhancers to modify the body is characterised in the light of three analytical perspectives: firstly the construction of personal experience and knowledge independently from existing institutions (the autonomous individual); secondly the ability to internalize external controls (the disciplined and socialized individual); thirdly the modification and personal ranking of norms imposed by existing institutions (the negotiating individual). In particular, the first mentioned perspective seems to be important in cases where an extreme physical training combined with drug-taking is a non-institutionalised practice and training and drug regimes are constructed in a kind of experimental way. Subjective interpretations that prove the practice are emphasised as an essential supplement to the more habitual and structural perspectives applied to a theoretical understanding and analysis of both the doping phenomenon and the legal use of pharmacentical substances for shaping the body within fitness culture.

Inge Kryger Pedersen, lektor, ph.d.

Sociologisk Institut

Københavns Universitet 